\title{
CIЧКАР B.I.
}

Селекиійно-генетичний інститут - Національний центр насіннєзнавства та сортовивчення, Україна, 65036, м. Одеса, Овідіопольська дорога, 3, e-mail: bobovi.sgi@ukr.net

\section{СЕЛЕКЦІЯ ЗЕРНОБОБОВИХ КУЛЬТУР НА ПОКРАЩЕННЯ СИМБІОТИЧНОЇ АЗОТФІКСАЦІї}

Зернобобові культури у світовому землеробстві займають друге місце після зернових як за посівними площами, так і валовими зборами. Незважаючи на це, їх виробництво постійно зростає. Так сою вирощують на площі біля 118 млн га, квасолю - на 30, нут - понад 15 , вігну 11, горох - 7 млн га. Польові боби, каянус, сочевицю, вику, люпин висівають на 1-5 млн га.

Така позитивна динаміка цих культур зумовлена тим, що вони є найбільш дешевим джерелом повноцінного білка, значний дефіцит якого існує на нашій планеті. У світі знаходиться значна кількість країн, особливо на африканському континенті, населення яких постійно недоїдає. На сьогоднішній день забезпечити їх повноцінним білком можна лише за рахунок зернобобових культур, поскільки він у 3-4 рази дешевший порівняно з тваринним.

Не менш важливе значення має ця група культур як поліпшувачі грунтів. За рахунок симбіотичної азотфіксації вони зв'язують значну кількість азоту із повітря, за допомогою мікоризних грибів перетворюють важкорозчинні фосфорні сполуки в доступну для сільськогосподарських культур форму. Бульбочки, які формуються на корінні рослин, $є$ центром, навколо якого розвивається комплекс корисних мікроорганізмів, куди входять симбіотичні, вільноживучі та мікоризні мікроорганізми.

Зв'язування молекулярного азоту із повітря являє собою досить складний біологічний процес, ефективність якого суттєво залежить від генетичних систем сорту рослини-господаря та штаму бульбочкових бактерій.

Мета наших досліджень полягала у виявленні найбільш цінних асоціацій «сорт-штам» у сої, гороху та нуту. Американські вчені вважають, що найбільш важливими науковими темами сьогодення $є$ генна інженерія, фотосинтез і біологічна фіксація азоту.

\section{Матеріали і методи}

Дослідження проводили у вегетаційних i польових умовах. У теплиці рослини вирощували у посудинах об'ємом 0,3 л на безазотному субстраті (вермикуліті), насиченому 0,2 \%-ним розчином $\mathrm{KH}_{2} \mathrm{PO}_{4}$. Перед сівбою насіння обробляли суспензією 7-добової культури ризобій із розрахунку $10^{6}$ бактерій/насінину. Щільність суспензії бульбочкових бактерій для дозування інокуляційного навантаження визначали на фотоелектроколориметрі КФК-2. Повторність дослідів 6-разова.

Польові дослідження закладали на полях дослідного господарства Селекційногенетичного інституту ДП ЕБ «Дачна», яке розташоване у південній частині Причорноморської низини, у степовій зоні Одеської області. Грунти являють типові південні середньогумусні важкосуглинисті чорноземи на лесових відкладеннях. Товщина гумусного шару $40-50 \mathrm{~cm}$, вміст гумусу - 3,5-4,5\%. Реакція грунтового розчину нейтральна або слаболужна.

Упродовж 2011-2015 рр., коли проводили дослідження, мали місце посушливі умови, які характеризувалися недостатньою кількістю опадів і підвищеними температурами повітря. Особливо спекотними були липень і серпень, коли у сої проходить формування та налив бобів. У зв'язку з цим показники продуктивності виявилися досить низькими як у дослідних, так i контрольних варіантах. Сівбу сої, гороху і нуту виконували селекційною сівалкою СКС-6-10, збирання комбайном «Сампо-130». Урожай насіння перераховували на $14 \%$-ну вологість. У процесі вегетації проводили фенологічні спостереження, необхідні обліки та оцінки. Кількість бульбочок і їх масу визначили у фазі цвітіння рослин.

У дослідженнях використовували штами бульбочкових бактерій Інституту фізіології рослин і генетики НАН України, сорти - Селекційно-генетичного інституту - Національного центру насіннєзнавства та сортовивчення.

(C) CIЧКАР B.I. 


\section{Результати та обговорення}

Рівень зв'язування азоту із повітря залежить від рослини-живителя (сорту), штаму бульбочкових бактерій, умов довкілля та їх взає- модії. У вегетаційних дослідах виявили неоднакову ефективність сортів за показниками симбіозу в середньому за використаними штамами бульбочкових бактерій (табл. 1).

Таблиця 1. Показники симбіозу нових сортів сої за інокуляції виробничими та перспективними штамами Bradyrhizobium japonicum

\begin{tabular}{|c|c|c|c|c|c|c|c|c|c|c|c|c|}
\hline \multirow[t]{2}{*}{ Сорт } & \multicolumn{3}{|c|}{$\begin{array}{c}\text { Кількість бульбо- } \\
\text { чок }\end{array}$} & \multicolumn{3}{|c|}{$\begin{array}{c}\text { Маса бульбочок на } \\
\text { рослині, мг }\end{array}$} & \multicolumn{3}{|c|}{$\begin{array}{l}\text { Нітрогеназна акти- } \\
\text { вність, мМоль ети- } \\
\text { лену/годину }\end{array}$} & \multicolumn{3}{|c|}{$\begin{array}{c}\text { Надземна маса про- } \\
\text { ростків, Г }\end{array}$} \\
\hline & $\begin{array}{c}2011 \\
\text { p. }\end{array}$ & $\begin{array}{l}2012 \\
\text { p. }\end{array}$ & $\begin{array}{c}\text { серед- } \\
\text { ня }\end{array}$ & $\begin{array}{l}2011 \\
\text { p. }\end{array}$ & $\begin{array}{l}2012 \\
\text { p. }\end{array}$ & $\begin{array}{c}\text { серед- } \\
\text { ня }\end{array}$ & $\begin{array}{l}2011 \\
\text { p. }\end{array}$ & $\begin{array}{c}2012 \\
\text { p. }\end{array}$ & $\begin{array}{c}\text { серед- } \\
\text { ня }\end{array}$ & $\begin{array}{c}2011 \\
\text { p. }\end{array}$ & $\begin{array}{l}2012 \\
\text { p. }\end{array}$ & $\begin{array}{l}\text { серед- } \\
\text { ня }\end{array}$ \\
\hline & 4,6 & 14,2 & 9,4 & 17,5 & 80,2 & 48,8 & 1,3 & 0,8 & 1,0 & 4,0 & 5,3 & 4,6 \\
\hline Ятрань & 25,1 & & & $25, \pi$ & & &,+ 0 & & 2, & & & 5,2 \\
\hline Симфо & 5,2 & & & 42,8 & & & 1,2 & & & 3 , & & 4,6 \\
\hline & & & & & & & & & & & & \\
\hline Фенікс & 12,4 & 20,8 & 16,6 & 72,5 & 118,2 & 95,4 & 2,1 & 1,7 & 1,9 & 5,2 & 5,8 & 5,5 \\
\hline
\end{tabular}

Незважаючи на значну варіабельність показників симбіозу стосовно до сортів і штамів, нами виявлено ряд цінних комбінацій, які являють значну цінність для практичного використання. Наприклад, на рослинах сорту Ятрань за інокуляції експериментальним штамом X-9 в середньому за два роки сформувалося 31,2 бульбочок, тоді як у сорту Аркадія одеська всього 6,5, а у сорту Сяйво - 10,4. Перевагу цього штаму за кількістю бульбочок на рослині спостерігали і у сорту Фенікс. У цілому штам X9 виявився найбільш продуктивним за кількістю бульбочок у всіх сортів, максимальне їх значення сформувалось на проростках сорту Ятрань. У середньому за інокуляції всіма штамами на рослинах сорту Ятрань нарахували 19,1 бульбочок, тоді як у сорту Аркадія одеська їх кількість становила 9,4, а у сорту Симфонія - 10,6.

Серед вивчених сортів за всіма показниками симбіозу виділяється сорт Ятрань. У середньому за два роки він був кращим за кількістю і масою бульбочок та нітрогеназною активністю. Непогані азотфіксувальні ознаки продемонстрував і сорт Сяйво, особливо у 2012 році, він мав найбільші показники кількості та маси бульбочок, нітрогеназної активності та надземної маси проростків (табл. 1). Нітрогеназна активність у вивчених сортів виявилася невисокою, що можна пояснити підвищеними температурами під час проведення досліджень.
Одержані результати чітко підтверджують ідею про те, що шляхом селекції макросимбіонта можна суттєво покращити показники симбіозу за використання нових штамів Bradyrhizobium japonicum. Але для добору найбільш активних компонентів необхідно випробовувати значний набір як генотипів, так і штамів.

Підвищений рівень бульбочок і їх маси за інокуляції виробничим штамом бактерій виявили також у селекційних ліній, створених шляхом гібридизації (табл. 2).

Аналіз їх походження свідчить про те, що у більшості із них однією батьківською формою $\epsilon$ сорт або лінія місцевої селекції. Наприклад, лінія № 119/14 була виділена із комбінації NS2024 х Хаджибей, № 133/14 - із Л1085/88 х Альтаїр, № 137/14 - із Чіко х Альтаїр, № 174/14 - із (ms1 Tonica x Tokyo) х Чарівниця степу. Батьківські форми, задіяні в цих гібридних комбінаціях, створені в Селекційно-генетичному інституті. Крім того, необхідно зазначити, що дослід був закладений на полі, де в грунті знаходяться спонтанні бульбочкові бактерії. Це свідчить про те, що виробничий штам Bradyrhizobium japonicum володіє непоганими конкурентними властивостями.

На основі визначення показників симбіозу упродовж ряду років створені лінії сої гібридного походження, які поєднують господарсько цінні ознаки з підвищеною кількістю бульбочок на рослині та їх масою. 
Таблиця 2. Кількість і маса бульбочок у посухостійких ліній сої

\begin{tabular}{|c|c|c|c|c|}
\hline \multirow{2}{*}{$\begin{array}{c}\text { Польовий № } \\
\text { лінії }\end{array}$} & \multicolumn{2}{|c|}{ Кількість бульбочок на рослині } & \multicolumn{2}{c|}{ Маса бульбочок на рослині, мг } \\
\cline { 1 - 4 } $\begin{array}{c}\text { Васильківська, } \\
\text { стандарт }\end{array}$ & 2014 р. & 2015 p. & 2014 p. & 2015 p. \\
\hline $119 / 14$ & $8,4 \pm 0,84$ & $6,3 \pm 0,58$ & $53,6 \pm 8,2$ & $37,1 \pm 4,4$ \\
\hline $120 / 14$ & $11,2 \pm 0,76$ & $8,7 \pm 0,62$ & $62,4 \pm 10,3$ & $45,2 \pm 5,8$ \\
\hline $130 / 14$ & $9,6 \pm 0,82$ & $10,3 \pm 0,64$ & $68,9 \pm 11,2$ & $56,3 \pm 5,9$ \\
\hline $133 / 14$ & $12,9 \pm 0,93$ & $6,7 \pm 0,52$ & $57,3 \pm 7,4$ & $35,8 \pm 2,8$ \\
\hline $137 / 14$ & $8,2 \pm 0,71$ & $6,8 \pm 0,60$ & $66,7 \pm 9,3$ & $48,8 \pm 5,7$ \\
\hline $139 / 14$ & $13,3 \pm 1,09$ & $11,2 \pm 0,83$ & $55,4 \pm 7,7$ & $41,6 \pm 5,1$ \\
\hline $174 / 14$ & $9,3 \pm 0,85$ & $6,7 \pm 0,48$ & $51,8 \pm 10,8$ & $48,6 \pm 6,2$ \\
\hline
\end{tabular}

Так, лінія сої № 220/11, виділена із комбінації ВІР 1884 х Аркадія одеська, характеризується підвищеною урожайністю насіння, більш високим вмістом білка в насінні та формує значно більше бульбочок на корінні. Під назвою Орфей вона передана до державного випробування.

Вплив штамів на урожай кожного сорту нуту суттєво залежить від умов року, які складалися в період вегетації (табл. 3).

Найбільш сприятливий водний статус мав місце у 2013 році, тоді як 2014 і 2015 роки ви- явилися посушливими, особливо в період від сходів до масового цвітіння, тобто у період найбільш інтенсивного росту коріння та бульбочок. Значною позитивною дією на продуктивність сортів Пам'ять та Буджак виділився штам А-44. На сорті Пам'ять досить ефективними були штами 065 і НC-6, які у роки із різним вологозабезпеченням дали суттєву прибавку врожаю. У симбіозі 3 сортом Буджак, який виділяється крупним насінням, штам 065 виявився неефективним, середній урожай його був на рівні контролю без обробки.

Таблиця 3. Урожайність сортів нуту залежно від обробки насіння штамами бульбочкових бактерій

\begin{tabular}{|c|c|c|c|c|c|c|c|c|}
\hline \multirow{2}{*}{ Штам } & \multicolumn{7}{|c|}{ Урожай насіння, ц/га } \\
\cline { 2 - 10 } & \multicolumn{7}{|c|}{ Пам'ять } & \multicolumn{4}{c|}{ Буджак } \\
\cline { 2 - 9 } & 2013 & 2014 & 2015 & сер. & 2013 & 2014 & 2015 & сер. \\
\hline $\begin{array}{c}\text { Контроль, без } \\
\text { інокуляції }\end{array}$ & 16,9 & 9,5 & 10,2 & 12,2 & 15,0 & 10,1 & 11,6 & 12,2 \\
\hline Н-12, ст. & 21,6 & 10,2 & 11,6 & 14,5 & 18,1 & 12,8 & 11,9 & 14,3 \\
\hline 065 & 21,4 & 11,9 & 11,9 & 15,1 & 15,8 & 10,2 & 12,1 & 12,7 \\
\hline 068 & 17,2 & 12,9 & 14,0 & 14,7 & 15,4 & 14,0 & 13,8 & 14,4 \\
\hline HС-6 & 17,4 & 14,0 & 14,2 & 15,2 & 15,2 & 12,0 & 15,6 & 14,3 \\
\hline А-44 & 21,0 & 13,5 & 12,1 & 15,5 & 18,0 & 12,4 & 14,6 & 15,0 \\
\hline HIP $_{05}$ & 1,58 & 0,98 & 1,11 & & 1,51 & 1,18 & 1,0 & \\
\hline
\end{tabular}

Наші багаторічні випробування перспективного селекційного матеріалу на фоні обробки штамами бульбочкових бактерій показали ефективність індивідуального відбору за показниками симбіозу.

Так, нами виділена лінія № 19/12, яка навіть у найбільш посушливі роки випробувань (2014 і 2015) за інокуляції штамами 065, 068 і А44 збільшувала урожайність на 20-25\%. Паралельно в цих варіантах мало місце збільшення кількості бобів на рослині та насінин у бобі, а також маси 1000 насінин. За результатами кон- курсного випробування інституту, лінію № 19/12 передаємо до державного сортовипробування під назвою Аргумент.

У 2012-2014 рр. провели випробування найбільш поширеного в Україні сорту гороху Світ та ліній Л 303/04 (Капітал) і Л 35/11 (Круїз) за інокуляції їх виробничим штамом 2616 і перспективними штамами К-29 і У-1. Вплив штамів на урожай сортів суттєво залежав від умов, які склалися в період вегетації (табл. 4).

Найбільш сприятливий водний статус мав місце у 2012 році, дуже посушливим був 2014 
рік. У сорту Світ позитивною дією виділився штам У-1, причому він був кращим протягом усього періоду досліджень. Цей штам також давав найбільшу прибавку врожаю сорту Капі- тал протягом 2012 і 2013 років, проте у 2014 році поступився штаму К-29.

У сорту Круїз протягом трьох років чітко виділився штам К-29.

Таблиця 4. Урожай сортів гороху за інокуляції насіння новими штамами

\begin{tabular}{|c|c|c|c|c|c|c|c|c|c|c|c|c|}
\hline \multirow{2}{*}{ Штам } & \multicolumn{4}{|c|}{ Світ } & \multicolumn{4}{|c|}{ Капітал (Л 303/04) } & \multicolumn{4}{|c|}{ Круїз (Л 35/11) } \\
\hline & 2012 & 2013 & 2014 & cep. & 2012 & 2013 & 2014 & cep. & 2012 & 2013 & 2014 & cep. \\
\hline $\begin{array}{c}2616, \\
\text { стандарт }\end{array}$ & 23,1 & 18,2 & 12,5 & 17,9 & 22,6 & 19,1 & 16,4 & 19,4 & 24,7 & 18,6 & 18,0 & 20,4 \\
\hline K-29 & 25,8 & 19,6 & 17,9 & 21,1 & 23,3 & 20,5 & 19,9 & 21,2 & 27,5 & 20,2 & 19,5 & 22,4 \\
\hline $\mathrm{Y}-1$ & 26,4 & 19,6 & 20,7 & 22,2 & 25,1 & 22,5 & 16,5 & 21,4 & 25,8 & 20,8 & 15,3 & 20,6 \\
\hline $\mathrm{HIP}_{0,5}$ & 1,58 & 1,38 & 1,03 & & 1,47 & 1,44 & 1,03 & & 1,59 & 1,46 & 1,03 & \\
\hline
\end{tabular}

\section{Висновки}

Одержані результати свідчать про те, що експериментальні штами $є$ значно кращими порівняно зі стандартним 261б. Лінія Л 35/11 3 покращеними показниками симбіозу, яка була передана до державного випробування під назвою Круїз, занесена до державного реєстру сортів рослин України з 2017 року. Продовжується вивчення сорту гороху Капітал у системі державного випробування.

\section{SICHKAR V.I.}

Plant breeding and Genetics Institute - National Center of Seed and Cultivar Investigation, Ukraine, 65036, Odessa, Ovidiopolskaya Road, 3, e-mail: bobovi.sgi@ukr.net

\section{BREEDING OF LEGUME CROPS FOR EFFECTIVE NITROGEN FIXATION}

Aim. Grain legume are able to accumulate $80-220 \mathrm{~kg} / \mathrm{ha}$ of nitrogen. To optimize this process we should select the complementary pairs "cultivar-strain", which could realize their maximum genetic potentials. We studied indices of symbiosis for the use of the number of experimental strains of soybean, pea and chickpea in laboratory and field conditions. Methods. The plants grown in containers of a volume of 0.31 without nitrogen in laboratory conditions. Field research conducted in rainfed conditions in the presence of spontaneous rhizobia in the soil. Results. Substantial variability was found for indices of the symbiosis of the interaction of different varieties of soybean, chickpea and pea with recommended and experimental strains of rhizobia. The best combination are recommended for use in different locations. Conclusions. The selected experimental strains of rhizobia, which are characterized by improved performance of the symbiosis of the varieties of soybean, chickpea and pea are recommended for using.

Keywords: rhizobium strains, nodulation, nitrogen fixation. 